\title{
ANALISIS PERKEMBANGAN JALAN TERHADAP PERKEMBANGAN KOTA: STUDI KASUS JALAN SIMPANG LIMA KOTA BAUBAU
}

\author{
Idwan \\ Program Studi Teknik Sipil, Fakultas Teknik \\ Universitas Muhammadiyah Buton, Jl. Betoambari No. 36 Baubau. \\ E-mail:idwan.civil@yahoo.com
}

\begin{abstract}
Abstrak
Penelitian dengan tujuan untuk mengetahui pengaruh jaringan jalan terhadap perkembangan kota Kecamatan Betoambari, dimana yang menjadi wilayah penelitian adalah jalan Simpang 5 (lima). Untuk mencapai tujuan dan sasaran penelitian metode analisis yang digunakan adalah analisis deskriptif kualitatif. Dari hasil analisis dapat dikatakan bahwa perkembangan jaringan jalan pada kawasan Simpang 5 (lima) dalam dua belas tahun terakhir mengalami peningkatan. Pada peta tahun 2003 jalan baru satu jaringan jalan saja dan belum terlihat bangun disempajang jalan tersebut, tetapi pada peta 2007, mulai terlihat adanya perkantoran pada jaringan jalan terebut dan pada peta 2014 mulailah terbentuk jaringan jalan simpang 5 (lima) dan pada jalan tersebut mulai tumbuh kawasan perkantoran, perumahan, permukiman dan ruang terbuka hijau.
\end{abstract}

Kata kunci: jaringan jalan, tata guna lahan, dan perkembangan kota.

\begin{abstract}
Research with the aim to know the influence of the road network on the development of the city of Betoambari District, where the research area is the Simpang 5 (five) road. To achieve the objectives and objectives of the research methods of analysis used is descriptive qualitative analysis. From the analysis it can be said that the development of the road network in the area of Simpang 5 (five) in the last twelve years has increased. On the map of 2003 a new road road is just one road and not yet visible woke up the road, but on the map 2007, began to appear the office on the road network and on map 2014 begin to form network intersection 5 (five) and on the road began to grow office area, housing, settlement and green open space.
\end{abstract}

Keywords: road network, land use, and city development. 


\section{SANG PENCERAH}

Volume 3, Nomor 2, Agustus 2017, Hlm. 30-38

Idwan: Analisis Perkembangan Jalan Terhadap Perkembangan ...

\section{Pendahuluan}

Perkembangan guna lahan akan terus meningkat seiring dengan perkembangan jumlah penduduk dan kegiatan sosial ekonomi penduduk yang menyertainya. Pertumbuhan penduduk mengakibatkan meningkatnya permintaan ketersediaan lahan yang akan dipergunakan untuk menyelenggarakan kegiatan. Pertumbuhan populasi dan ekonomi yang signifikan di pusat kegiatan kota, mengakibatkan perkembangan guna lahan ke arah pinggiran kota.

Pertumbuhan populasi yang pesat dikota-kota besar tidak hanya berarti bertambahnya jumlah manusia yang tinggal dan bekerja di kota tersebut, tetapi berimplikasi juga terhadap pertumbuhan perjalanan. Pertumbuhan perjalanan ini bukan hanya dari sisi jumlahnya saja, tetapi juga dalam panjang perjalanan karena areal kota bertambah luas seiring dengan meningkatnya kebutuhan ruang bagi kegiatan kota. Dalam kenyataannya, perkembangan guna lahan pada daerah tersebut telah diikuti oleh adanya kegiatankegiatan produktif yang mengisi ruang sepanjang jalan yang menghubungkan antar daerah pinggiran kota dan pusat kegiatan kota.

Seiring dengan adanya perkembangan tata guna lahan yang berbatasan dengan pusat kegiatan kota, sehingga jumlah pengguna jalan penghubung menuju dan keluar dari pusat kegiatan kota menjadi meningkat. Hal ini secara simultan dapat mengakibatkan penurunan kinerja jaringan jalan yang menuju dan keluar dari pusat kegiatan kota. Perkembangan dan perubahan jenis guna lahan mengakibatkan meningkatnya jumlah pergerakan dan hal tersebut memberikan dampak besar terhadap penurunan kinerja ruas jaringan jalan. Penurunan kinerja ruas jaringan jalan tersebut berupa volume lalu lintas, bertambahnya waktu perjalanan dan menurunnya kecepatan perjalanan yang memnyebabkan menigkatnya biaya perjalanan. Dapat disimpulkan bahwa tata guna lahan memiiki pengaruh terhadap sistem jaringan transportasi.

Dalam penelitian ini penulis mengambil studi kasus jalan simpang lima sebagai daerah studi, dengan alasan karena pada jaringan jalan tersebut terdapat beberapa kegiatan yaitu perkantoran, pemukiman/perumahan, pariwisata, perdagangan dan jasa, serta RTH. Ruas jaringan jalan tersebut merupakan salah satu jalan masuk menujuh Kota Baubau dan melayani arus lalu lintas yang masih normal. Berdasarkan uraian di atas, fokus penelitian ini adalah bagaimanakah perkembangan jalan terhadap perkembangan kota, studi kasus jalan Simpang Lima Kota Baubau.

Tujuan penelitian ini untuk mengetahui fungsi tata guna lahan di Kec. Betoambari, serta menganalisis kondisi jaringan jalan simpang 5 (lima) pada tahun 2003 sampai tahun 2014.

\section{Metode Penelitian}

\section{Lokasi Penelitian}

Lokasi penelitian ini di Jalan Simpang 5 (Lima), Kecamatan Betoambari Kota Baubau. Metode penelitian yang digunakan untuk menjawab tujuan masalah penelitian adalah:

1. Metode deskriptif kualitatif, digunakan untuk mengetahui kondisi fisik prasarana dasar pemukiman yang ada di Kec. Betoambari. Analisis deskriptif kualitatif ini dilakukan terhadap data yang telah diperoleh dari dokumentasi, wawancara, observasi lapangan.

2. Sedangkan analisis deskriptif kuantitatif, dilakukan terhadap perhitungan proyeksi penduduk dan kebutuhan prasarana.

3. Metode overlay peta

Overlay adalah prosedur penting dalam analisis SIG (Sistem Informasi Geografis). Overlay yaitu kemampuan untuk menempatkan grafis satu peta diatas 


\section{SANG PENCERAH}

Volume 3, Nomor 2, Agustus 2017, Hlm. 30-38

\section{Idwan: Analisis Perkembangan Jalan Terhadap Perkembangan ...}

grafis peta yang lain dan menampilkan hasilnya di layar komputer atau pada plot. Peta yang digunakan yaitu peta citra dari tahun 2003, 2007 dan tahun 2014.

\section{Pembahasan}

\section{Karateristik Kependudukan}

Hasil proyeksi penduduk tahun 2015, jumlah penduduk di Kecamatan Betoambari mencapai 18.433 orang dengan rasio jenis kelamin dibawah angka 100, ini menunjukkan bahwa jumlah penduduk perempuan sebesar 9.342 orang lebih banayak dari pada jumlah penduduk lakilaki yang hanay sebesar 9.091 orang.

\section{Tabel 1 Statistik Kependudukan}

\begin{tabular}{ccc|}
\hline Uraian & Satuan & $\mathbf{2 0 1 5}$ \\
\hline Penduduk & Orang & 18.433 \\
Laki-laki & Orang & 9.091 \\
Perempuan & Orang & 9.342 \\
Laju pertumbuhan & & 2,27 \\
Kepadatan & Orang/Km² & 587 \\
Rasio & & 97.31 \\
Rumahtangga & & 3.938 \\
\hline
\end{tabular}

Sumber : Betoambari Dalam Angka 2016

Pada tahun 2015 jumlah rumah tangga di kecamatan betoambari mencapai 3.938 dengan rata-rata anggota per rumah tangga sebesar 4.7. untuk tingkat kepadatan penduduk kecamatan betoabari mencapai 587 orang per $\mathrm{km}^{2}$, dimana Kelurahan Katobengke merupakan kelurahan terpadat yang mencapai 8.763 orang per $\mathrm{km}^{2}$. Sama halnya dengan persebaran penduduk, selama tahun 2015 sebesar 47,54 persen penduduk Kecamatan Betoambari berada di Kelurahan Katobengke, hal ini menunjukkan belum meratanya tingkat persebaran penduduk.

Tabel 2 Jumlah Penduduk dan Lajur Pertumbuhan Penduduk di Kecamatan Betoambari, 2014 - 2015

\begin{tabular}{lccc}
\hline Kelurahan & $\begin{array}{c}\text { Jumlah Penduduk } \\
\text { (orang) }\end{array}$ & $\begin{array}{c}\text { Laju } \\
\text { Pertumbuhan } \\
\text { Penduuduk per } \\
\text { tahun (\%) }\end{array}$ \\
\cline { 2 - 4 } & $\mathbf{2 0 1 4}$ & $\mathbf{2 0 1 5}$ & $\mathbf{2 0 1 4 - \mathbf { 2 0 1 5 }}$ \\
\hline Sulaa & 1.747 & 1.787 & 2,29 \\
Waborobo & 1.204 & 1.230 & 2,16 \\
Lipu & 5.523 & 5.649 & 2,28 \\
Katobengke & 8.567 & 8.763 & 2,29 \\
Labalawa & 982 & 1.004 & 2,24 \\
Betoambari & 18.023 & 18.433 & 2,27 \\
\hline
\end{tabular}

\section{Transportasi}

Perkembangan sarana transportasi di Kecamatan Betoambari semakin menunjukan peningkatan yang cukup signifikan dari tahun ke tahun. Pada tahun 2015 sarana transportasi di beberapa kelurahan di dominasi oleh adanya alat transportasi sepeda motor (ojek) seperti di Kelurahan Waborobo, Lipu, Katobengke dan Labalawa dengan biaya pulang pergi sebesar enam ribu sampai dengan dua puluh ribu rupiah. Sementara untuk Kelurahan Sulaa, umumnya menggunakan alat transportasi mobil angkutan umum (mikrolet) dengan biaya pulang pergi sebesar enam ribu rupiah.

Banyaknya kendaraan bermotor terdaftar menurut jenis kendaraan di Kecamatan Betoambari pada tahun 2015, yakni untuk jenis mobil penumpang sebanyak 25 unit, mobil barang sebanyak 66 unit serta mobil bus sebanyak 224 unit.

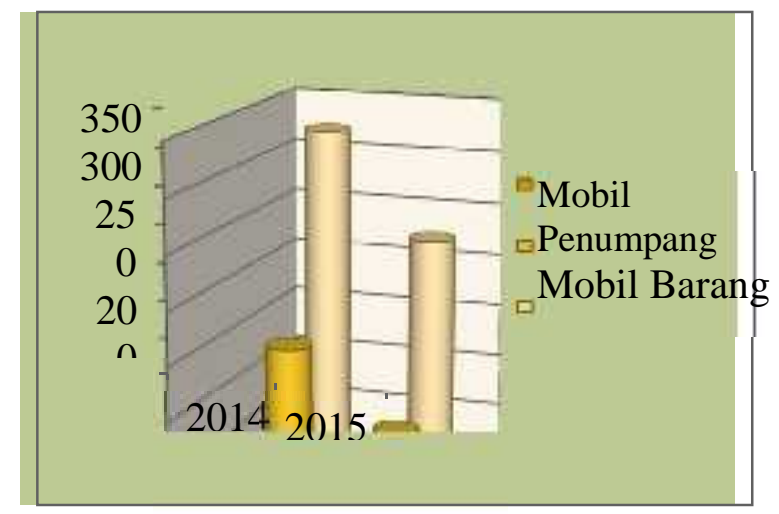

Diagram 1 Banyaknya Kendiraan Terdaftar di Kecamatan Betoambari, 2014-2015 


\section{SANG PENCERAH}

Volume 3, Nomor 2, Agustus 2017, Hlm. 30-38

Idwan: Analisis Perkembangan Jalan Terhadap Perkembangan ...

Tabel 3 Statistik Transportasi

\begin{tabular}{|lcr|}
\hline Kelurahan & $\begin{array}{c}\text { Alat Transportasi } \\
\text { dari Kelurahan ke } \\
\text { Kantor Kecamatan }\end{array}$ & $\begin{array}{c}\text { Biaya } \\
\text { PP }\end{array}$ \\
\hline Sulaa & Mikrolet & 6000 \\
\hline Waborobo & Ojek & 20000 \\
\hline Lipu & Ojek & 6000 \\
\hline Katobengke & - & - \\
\hline Labalawa & Ojek & 20000 \\
\hline
\end{tabular}

Sumber : Betoambari Dalam Angka 2016

\section{Kondisi Jaringan Jalan Simpang 5 (Lima) terhadap Perkembangan Kota di Kecamatan Betoambari.}

\section{Fungsi Jalan}

Jaringan jalan 1 (satu) berfungsi sebagai jalan arteri sekunder, dengan lebar $\mathrm{ROW} \pm 12$ dan lebar perkerasan \pm 8 $\mathrm{m}$. Jalan ini dalam kondisi baik, dengan perkerasan jalan berupa aspal, dan sebagian kecil dalam kondisi rusak ringan berupa retak kulit buaya pada beberapa titik di sisi-sisi jalan baik kiri maupun kanan jalan. Jaringan jalan 1 (satu) menunjukkan bahwa jalan tersebut berfungsi untuk melayani kendaraan roda dua, tiga dan empat yang mengarah kearah kawasan pusat perkantoran dan kawasan perumahan.

Jaringan jalan 2 (dua) berfungsi sebagai jalan kolektor sekunder, dengan lebar $\mathrm{ROW} \pm 10 \mathrm{~m}$ dan lebar perkerasan $\pm 6 \mathrm{~m}$. Jalan ini dalam kondisi baik,dengan perkerasan jalan berupa aspal dan sebagian kecil dalam kondisi rusak ringan berupa retak kulit buaya pada beberapa titik di sisi-sisi jalan baik kiri maupun kanan jalan. Jaringan jalan 2 (dua) ini memiliki dapat menghubungkan antara dua kelurahan antara lain Kelurahan Waborobo dengan Kelurahan Sulaa. Terlepas dari itu jalan tersebut terdapat kawasan perumahan. Jaringan jalan 3 berfungsi sebagai jalan kolektor sekunder, dengan ROW \pm 10 m dan lebar perkerasan $\pm 6 \mathrm{~m}$. Jalan ini dalam kondisi baik,dengan perkerasan jalan berupa aspal dan sebagian kecil dalam kondisi rusak ringan berupa retak buaya pada beberapa titik di sisi-sisi jalan baik kiri maupun kanan jalan.

Fungsi jaringan jalan yang ke 3 (tiga) merupakan sistem jaringan jalan yang menghubungkan antarkawasan di dalam perkotaan yang diatur secara berjenjang sesuai dengan fungsi kawasan yang dihubungkannya. Dari hasil pengamatan, Jaringan jalan 4 (empat) dengan lebar ROW $\pm 12 \mathrm{~m}$ dan lebar perkerasan $\pm 8 \quad \mathrm{~m}$ berfungsi menghubungkan kawasan sekunder kesatu dengan perumahan, kawasan sekunder kedua dengan perumahan, kawasan sekunder ketiga dan seterusnya sampai ke perumahan. Menurut RTRW jalan tersebut termasuk jalan lokal. Tetapi dari hasil pengamatan tersebut termasuk jalan lokal sekunder.

\section{Kelas Jalan Berdasarkan Beban Muatan Sumbu}

Dari hasil pengamatan, jaringan jalan 2 (dua) dengan lebar ROW $\pm 10 \mathrm{~m}$ perkerasan $\pm 6 \mathrm{~m}$. Sperti yang terlihat pada gambar kedua sisi jalan belum terlihat adanya permukiman atau perumahan. Jalur yang dapat dilalui kendaraan mulai dari roda dua, tiga dan empat. Dan berada jalan kelas III B, yaitu jalan kolektor yang dapat dilalui kendaraan bermotor termasuk muatan dengan ukuran lebar tidak melebihi 2.500 milimeter, ukuran panjang tidak melebihi 12.000 milimeter, dan muatan sumbu terberat yang diizinkan 8 ton.

Dari arah bundaran simpang 5 (lima), jaringan jalan 3 (tiga) yang memiliki lebar ROW $\pm 10 \mathrm{~m}$ dengan lebar perkerasan $\pm 6 \mathrm{~m}$. Dari hasil pengamatan, ada beberapa titik yang telah dilakukannya peningkatan jalan dengan lebar ROW $\pm 12 \mathrm{~m}$ dengan lebar 


\section{SANG PENCERAH}

Volume 3, Nomor 2, Agustus 2017, Hlm. 30-38

\section{Idwan: Analisis Perkembangan Jalan Terhadap Perkembangan ...}

perkerasan $\pm 8 \mathrm{~m}$ dapat dikelompokan menjadi jalan kelas III B, yaitu jalan kolektor yang dapat dilalui kendaraan bermotor termasuk muatan dengan ukuran lebar tidak melebihi 2.500 milimeter, ukuran panjang tidak melebihi 12.000 milimeter, dan muatan sumbu terberat yang diizinkan 8 ton.

Jalan yang menghubungkan antara kawasan perumahan dan Menara Pandang Polima dan baru selesai di lakukan peningkatan jalannya. Hal tersebut dapat dilihat dari aspal yang masih baru. Dari hasil pengamatan yang saya lakukan bahwa jalan tersebut masuk dalam jalan kelas III kolektor.

\section{Jumlah Jalur}

Dari hasil pengamatan, jumlah lajur yang terdapat pada jalan yang menghubungkan antara perkantoran dan perumahan. Dari arah keraton menuju kantor walikota terdapat dua lajur, sedangkan dari arah kantor walikota menuju kawasan perumahan hanya memiliki 1 (satu) lajur. Jalur yang terdapat pada jaringan jalan 3 (tiga) memeiliki lebar $\mathrm{ROW} \pm 10 \mathrm{~m}$ dengan lebar perkerasan $\pm 6 \mathrm{~m}$. Jalan yang mengarah ke Kelurahan Waborobo tersebut, terdapat pula kaawasan perumahan. Dari hasil pengamatan dilapangan, dapat disimpulkan bahwa jalan tersebut hanya memiliki satu jalur. Seperti yang terlihat pada gambar diatas menunjukkan bahwa jalan yang menghubungkan antar kawasan perumahan terdapar satu jalur saja, ini dikarenakan jalan tersebut baru sebagian saja yang dilakukannya peningkatan jalan.

Jaringan jalan 4 (empat) yang menghubungkan antar kawasan perumahan dengan pemukiman yang berada di Desa Topa.telah selesai dilakukannya pningkatan jalan, hal ini dapat terlihat dari badan jalan yang memiliki lebar $\pm 8 \quad \mathrm{~m}$. Dari hasil poengamatan yang dilakukan baru satu jalur yang terlihat.

\section{Jumlah Arah dan Pembagian Lajur}

Dari hasil pengamatan, jaringan jalan 1 (satu) yang mengarah menuju kantor walikota dan perumahan terdapat dua tipe jumlah arah dan pembagian jalur:

1) Arah yang menuju kantor walikota terdapat dua lajur yaitu kiri dan kanan dengan lebar $\mathrm{ROW} \pm 12 \mathrm{~m}$ dan lebar perkerasan $\pm 8 \mathrm{~m}$

2) Arah dari kantor walikota sampai perumahan atau bundaran simpang 5 (lima) terdapat satu arah lajur.

Dari hasil pengamatan dilapangan, diketahui bahwa jalan yang mengarah ke Kelurahan Waborobo dengan lebar ROW $\pm 10 \mathrm{~m}$ dan lebar perkerasan $\pm 6 \mathrm{~m}$ hanya satu arah dan satu lajur. Diliat dari gambar diatas perlu adanya pelebaran, karena jalan tersebut adalah jalur penghubung antara Kelurahan Sulaa dan Kelurahan Waborobo. Dari hasil pengamatan, jumlah arah dan pembagian lajur hanya satu arah dan satu lajur, ini dikarenakan jalan yang hanya mempunyai lebar ROW \pm 10 dan lebar perekerasan $\pm 6 \mathrm{~m}$, belum terlalu banyak dilalui kendaraan, jadi untuk aktifitas arus lalulintasnya masih sangat rendah. Tetapi tidak menutup kemungkinan akan ada pembagian lajur, karena di beberapa titik suda dilakukannya peningkatan jalan dengan lebar ROW $\pm 12 \mathrm{~m}$ dan lebar perkerasan $\pm 8 \mathrm{~m}$.

Dari hasil pengamatan, jaringan jalan 4 (empat) dengan menghubungkan antar kawasan perumahan. Seperti yang terlihat di gambar bahwa jumlah arah dan lajur pada jalan tersebut hanya terdapat satu arah dan satu lajur. Tetapi , tidak menutup kemungkinan ketika ada pemanfaatan guna lahan maka bisa 


\section{SANG PENCERAH}

Volume 3, Nomor 2, Agustus 2017, Hlm. 30-38

\section{Idwan: Analisis Perkembangan Jalan Terhadap Perkembangan ...}

dipastikan akan di berlakukannya dua lajur.

\section{Lebar Jalur}

Dari hasil pengamatan dilapangan, jalan di sepanjang kawasan perkantoran dan perumahan memiliki lebar jalaur \pm 8 $m$ dan sebagian sisi jalan terdapat drainase.

Dari hasil pengamatan, jaringan jalan 2 (dua) yang mengarah ke kawasan perumahan dan ke Kelurahan Waborobo memiliki lebar jalur $\pm 6 \mathrm{~m}$. Hal ini perlu dilakukannya peningkatan jalan oleh pemerintahan setempat. Dari hasil pengamatan, jaringan jalan 3 (tiga) yang mengarah ke perumahan memiliki lebar berwariasi diantaranya dari bundaran simpang lima sampai kawasan perumahan yang memiliki jarak $\pm 50 \mathrm{~m}$ dengan lebar badan jalan $\pm 6 \mathrm{~m}$, sedangkan yang dari kawasan tersebut. Sampai jalan yang menembus pantai nirwana memiliki lebar $\pm 8 \mathrm{~m}$.

Dari hasil pengamatan, jaringan jalan 4 (empat) yang mengarah pada kawasan perumahan dengan ROW \pm 12 $\mathrm{m}$ dan Lebar perkerasan $\pm 8 \mathrm{~m}$. Dapat di pastikan untuk jalur pada gambar diatas mempunyai lebar jalur $\pm 8 \mathrm{~m}$.

\section{Arus Lalu Lintas}

\section{a. Kendaraan yang Melintas}

Dari hasil pengamatan, arus lalu lintas pada jaringan jalan 1 (satu) termasuk kepadatan arus lalulintas sangat rendah. Di karenakan fungsi guna lahan dijalan ini berupa perumahan perkantoran dan perdagangan (kios/warung), dari kegiaan fungsi guna lahan tersebut nampak aktifitas antar kawasan sangat rendah. Namun menurut RTRW Kota Baubau disepanjang jalan ini diarahkan fungsi pola ruagnya sebagai pusat perkantoran pemerintahan, perumahan dan RTH. Menurut RTRW $\mathrm{k}$ ta Baubau, perkembangan kota diarahkan di Kecamatan Betoambari sebagai pusat perkembangan baru yang termasuk dalam lokasi penelitian ini. Seperti yang nampak pada saat ini, dimana mulai tumbuh kawasan permukiman baru yang dibangun oleh developer secara masal.

Dari hasil pengamatan, pada jaringan jalan 2 (dua) dengan lebar ROW \pm 10 dan lebar perkerasan $\pm 6 \mathrm{~m}$. Tingkat kepadatan arus lalulintas dijalan tersebut masih sangat rendah. Hal tersebut mungkin dikarenakan tingkat aktifitas dikawasan tersebut masih sangat rendah. Dari hasil pengamatan, jaringan jalan 3 (tiga) yang memiliki ROW $\pm 12 \mathrm{~m}$ dan lebar perkerasan $\pm 8 \mathrm{~m}$ dapat dipastikan untuk aktifitas arus lalulintas di jalan tersebut masih sangat rendah. Ini dapat di lihat dari gambar di atas yang menunjukkan tidak ad anya kendaraan yang melintas dijalan tersebut.

Dari hasil pengatan di lapangan, untuk kendaraan yang melintas pada jalur ini sangat rendah. Di karenakan pada jalur tersebut, untuk wilayah sisi kiri dan kanan belum terlihat adanya kawasan seperti perumahan jadi untuk kendaran yang milintas masih sangat rendah.

\section{b. Trotoar}

Dari hasil pengamatan, jaringan jalan 1 (satu) yang mengarah pada kawasan perkantoran dan perumahan. Setelah diamati pada jalan tersebut dapat di simpulkan tidak adanya trotoar, dikarenakan jalur tersebut masih kurang dilalui para pejalan kaki. Dari hasil pengamatan, jaringan jalan 2 (dua) belum adanya peningkatan jalan itu bisa dilihat dari gambar diatas. Jalan dengan lebar ROW \pm 10 dan lebar perkerasan $\pm 6 \mathrm{~m}$ belum terlihat 


\section{SANG PENCERAH}

Volume 3, Nomor 2, Agustus 2017, Hlm. 30-38

\section{Idwan: Analisis Perkembangan Jalan Terhadap Perkembangan ...}

trotoar. Hal tersebut dikarenakan masih minimnya pejalan kaki, karena disepanjang jalan tersebut belum banyak interaksi antar kawasan perumahan atau kawasan lainnya masih sangat rendah.

Seiring berjalannya waktu, fakta menunjukkan bahwa kondisi trotoar sekarang sudah tidak sesuai lagi dengan definisinya. Dari hasil pengamatan, gambar diatas untuk jaringan jalan 3 (tiga) tidak tampak terlihat trotoar dijalan tersebut. Trotoar tidak hanya milik pejalan kaki, banyak pihak yang memanfaatkan trotoar mulai dari tukang parkir hingga pedagang kaki lima. Aktivitas seperti ini tak hanya merugikan pejalan kaki, tetapi juga menimbulkan masalah baru, seperti kemacetan akibat terganggunya mobilitas kendaraan dengan aktivitas yang tidak tepat pada tempatnya. Dari hasil pengamatan, bisa dilihat dari gambar diatas belum terdapatnya trotoar.

c. Bahu Jalan

Berdasarkan hasil pengamatan, pada jaringan jalan 1 (satu) dan 2 (dua), dapat lihat pada gambar diatas adanya bahu jalan namun kondisinya tidak terawat. Hal ini terlihat dari tingginya rumput di pinggir jalan sepanjang jalur tersebut. Dari hasil pengamatan, jalan yang mengarah pada kawasan perumahan terlihat adanya bahu jalan. Dikarenakan dari perencanaan jalan ada diadakannya bahu jalan. Dari hasil peneletian, jaringan jalan 1 (satu) dan 2 (dua) terlihat pada gambar bahu jalan yang hanya dibuat dari perkerasan jalan tanpa bahan pengikat, biasanya digunakan matrial agregat bercampur sedikit lempung, dipergunakan untuk daerah-daerah yang tidak begitu penting, dimana kendaraan yang berhenti dan mempergunakan bahu jalan tidak begitu banyak jumlahnya.

d. Median

Berdasarkan hasil pengamatan, di ketahui seluruh jaringan jalan tidak memiliki median. Dikarenakan lebar rata-rata jalan $\pm 8 \mathrm{~m}$ dan tingkat kepadatan arus lalulintas masih sangat rendah.

\section{e. Drainase}

Jaringan jalan 1 (satu) yang mengarah kekawasan perkantoran terdapat drainase pada salah satu sisi jalan dengan lebar $30 \mathrm{~cm}$, panjang \pm 40 $\mathrm{m}$ dengan kedalaman $35 \mathrm{~cm}$. Jaringan jalan 2 (dua) yang mengarah kekawasan perumahan serta menuju Kelurahan Waborobo dengan ukuran lebar kurang lebih ROW $\pm 10 \mathrm{~m}$ dengan lebar perkerasan $\pm 6 \mathrm{~m}$ tanpa drainase, namun pada musim penghujan tidak terjadi genangan karena di sisi kiri dan kanan masih tinggi.Jika diliat dari lebar ROW yang tersidia dijalan kedua, maka telah disediakan tempat untuk membangun drainase selebar kurang lebih satu m disetiap sisi jalan (sisi kiri dan kanan).

Jaringan jalan 3 (tiga) yang mengarah pada kawasan perumahan yang memiliki lebar perkerasan $\pm 8 \mathrm{~m}$ setelah dilakukan peningkata jalan dan masih ada bebarapa titik yang belum diadakannya peningkatan jalan. Jaringan jalan 4 (empat) yang mengarah pada kawasan antar perumahan dengan lebar badan jalan $\pm 8 \mathrm{~m}$ belum memiliki drainase di karenakan jalan tersebut baru selesai dibangun.

\section{f. ROW}

Dari hasil pengamatan, terlihat bahwa jalan yang menuju kawasan perumahan memiliki ROW $\pm 12 \mathrm{~m}$ dan lebar perkerasan $\pm 8 \mathrm{~m}$.

\section{g. Marka Jalan}

Jalan yang mengarah ke arah kawasan perkantoran dan perumahan 


\section{SANG PENCERAH}

Volume 3, Nomor 2, Agustus 2017, Hlm. 30-38

\section{Idwan: Analisis Perkembangan Jalan Terhadap Perkembangan ...}

dengan lebar $\pm 8 \mathrm{~m}$ terdapat marka jalan.

1. Simbol pertigaan yang menuju rumah sakit, kantor walikota dan arah kebenteng keraton;

2. Penanda arah ke rumah sakit;

3. Papan nama jalan; serta

4. Baleho yang di pasang tanpa ada ijin.

Jalan yang mengarah pada
kawasan
menghubungkan Kelurahan Sulaa dan Kelurahan Waborobo dengan lebar perkerasan $\pm 6 \mathrm{~m}$ tidak memiliki marka jalan. Dari hasil pengamatan dilapangan, jaringan jalan 3 (tiga) dengan lebar $\mathrm{ROW} \pm 12 \mathrm{~m}$ dan lebar perkerasan $\pm 8 \mathrm{~m}$ belum terlihat adanya marka jalan. Dikarenakan jalan tersebut masih baru dan arus lalulintasnya masih sangat rendah. Dari hasil pengamatan, jaringan jalan 4 (empat) yang mengarah pada kawasan perumahan. Sama dengan jalan ke tiga belum terlihat pula marka jalan, dikarenakan jalan tersebut masih baru dan tingkat kepadatan kendara masih rendah.

\section{Analisis Jaringan Jalan Terhadap Perkembangan Kota}

Sistem jaringan jalan di Kota Baubau tidaklah berdiri sendiri, melainkan terjadi karena ada unsur pembentuknya. Perilaku penduduk dan kegiatan sosial ekonomi kota ikut andil dalam terbentuknya jaringan jalan kota yang merupakan fenomena dari kegiatan transportasi kota. Karakteristik sosial ekonomi penduduk, penggunaan lahan, ketersediaan sarana dan prasarana transportasi, dan pola pergerakan penduduk merupakan faktor-faktor terbentuknya jaringan jalan. Pada peta 2003 jaringan jalan simpang 5 (lima) belum nampak terlihat jalan aspal melainkan jalan tanah yang nampak terlihat pada jalan tersebut, dengan panjang $\pm 1,8 \mathrm{~km}$ untuk jaringan 1 dan $\pm 2 \mathrm{~km}$ pada jaringan 2 .

Pada peta sebaran bangunan dan jaringan jalan 2007, jaringan jalan dari arah keraton nampak terlihat walau masih berupa jalan tanah dengan panjang $\pm 1,2 \mathrm{~km}$ pada jaringan jalan yang mengarah pada kantor walikota sedangkan jalan terdapat 3 jaringan jalan saja.

Untuk jalan sekitar simpang 5 (lima) mulai terbentuk sekitar tahun 2005 terbangunnya jaringan jalan ini seiring dengan mulai diarahkannya kawasan pusat perkantoran pemerintahan Kota Baubau di sekitar jalan ini. Pada awalnya jalan yang terbentuk hanya 1 jalan sajah yakni jalan arteri sekunder saat ini. Selang 1 tahun terbangunnya jalan dan sarana perkantoran pemerintahan, maka mulai terlihat kawasan permukiman tumbuh disepanjang jalan arteri sekunder ini. Melihat prospek yang sangat baik dari terbangunnya jaringan jalan ini dimanfaatkan oleh para developer yang selanjutnya pada tahun ke 2 hingga ke 3, mulai tumbuh kawasan perumahan di sepanjang jalan simpang 5 (lima).

Pada peta 2017 terlihat 3 jaringan jalan dan masing-masing jalan memiliki panjang yang berwariasi. Jaringan jalan yang mengarah pada kantor walikota memiliki panjang $\pm 1,3 \mathrm{~km}$ sedangkan yang 2 jaringan lainnya lihat pada gambar 4.59. Hingga saat ini terus tumbuh di beberapa titik kawasan perumahan, karena berdasarkan arahan RTRW Kota Baubau Tahun 2014-2034, dimana Kecamatan Betoambari khususnya disekitar jalan simpang 5 (lima) akan diarahkan sebagai kawasan perumahan baru, dan kawasan perdagangan dan jasa, namun kawasan perdagangan belum nampak pembangunannya saat ini. Saran perdagangan yang ada hanya berupa skala lingkungan saja.

Jaringan jalan yang diambil pada tahun 2014 nampak terlihat perkembangan jaringan jalan dengan 5 jaringan jalan utama dengan 1 jaringan jalan yang belum 


\section{SANG PENCERAH}

Volume 3, Nomor 2, Agustus 2017, Hlm. 30-38

\section{Idwan: Analisis Perkembangan Jalan Terhadap Perkembangan ...}

terselesaikan. Pada jaringan jalan yang mengarah ke Kelurahan Waborobo memiliki panjang $\pm 1,4 \mathrm{~km}$ sedangkan dari kawasan perumahan yang mengarah pada jalan poros Baubau-Batauga memiliki panjang $\pm 1,9 \mathrm{~km}$. Dengan demikian jaringan jalan simpang 5 (lima) ini sangat berpengaruh terhadap perkembangan kota Baubau khususnya di Kecamatan Betoambari guna mengantisipasi perkembangan pusat kota Baubau yang semakin padat penduduk dan aktivitasnya. Untuk saat ini, jaringan jalan yang ada masih memenuhi kebutuhan kegiatan di sekitar jalan simpang 5 (lima) maupun sekitarnya. Namun untuk kedepannya diperlukan upaya peningkatan kualitas dan kuantitas baik untuk jalan simpang 5 (lima) maupun disekitar jalan simpang 5 (lima) terutama pada jalan-jalan lokal dan lingkungan.

\section{Simpulan}

Simpulan penelitian ini bahwa (1) Fungsi tata guna lahan di wilayah kecamatan Betoambari jalan Simpang 5 (lima) sebagai daerah perkantoran, perumahan, permukiman dan RTH suda sesuai dengan RTRW Kota Baubau. Dikarenakan kawasan penelitian ini, merupakan kawasan strategis yang dikembangkan sesuai dengan fungsinya sehingga akan tercipta keterkaitan antara fungsi kawasannya dengan beberapa fungsi lain disekitarnya; (2) Kondisi jaringan jalan simpang 5 (lima) fungsinya sebagai jalan kolektor sekunder, pada umumnya baik dengan perkerasaan permukaan berupa aspal tanpa dilengkapi jalur pejalan atau trotoar, belum terdapat drainase di beberapa titik jalan. Keterkaitannya dengan perkembangan Kota Baubau. Pada tahun 2003 kawasan simpang 5 (lima) belum nampak terlihat jalan aspal, namun suda terlihat jalan tanah. namun, kawasan RTH dalam hal ini taman kota, kawasan permukiman dan permuhan belum nampak terlihat. Pada tahun 2007 kawasan jalan simpang 5 (lima) mulai berkembang jalan, namun masih jalan tanah, serta suda nampak perkantoran. Pada tahun 2014 jaringan jalan pada simpang lima sudah terlihat jalan aspal dan beberapa jalan lingkungan serta RTH, perkantoran, permukiman dan perumahan.

\section{Daftar Pustaka}

Badan Pusat Statistik Kota Baubau. 2015. Bps Kecamatan dalam Angka Tahun 2015.

Bourne. L.S. 1982. Internal Structure Of City. New York: Oxford University,Press

Chapin, f.suart. Jr, and kaiser, edward j, 1979. Urban land use planning.3rd, Urbana, University Of Illois Press.

Djoko, Sujarto. 1991. Masalah Peremajaan Kota, ITB, Bandung.

Jayadinata, J.T. 1999. Tata Guna Tanah Dalam Perencanaan Pedesaan, Perkotaan dan Wilayah. Bandung: Penerbit ITB.

Karyoedi. 1987. Manajemen Lahan Perkotaan dan Pembangunan. Jakarta: Penerbit Universitas Indonesia.

Koestoer, R.H, dkk. 2001. Dimensi Keruangan Kota. Jakarta: Penerbit Universitas Indonesia.

Sandy, I. Made. 1982. Pembngunan Wilayah. Bogor: Mimograft.

Warpani, S. 1984. Analisa kota dan daerah. Bandung: ITB. 